\title{
Damage Estimation using Shock Zones: A case study of Amphan tropical cyclone
}

\author{
Medha ( $\square$ medha.1395@gmail.com ) \\ Jawaharlal Nehru University \\ Biswajit Mondal \\ Jawaharlal Nehru University \\ Gour Doloi \\ Panskura Banamali College
}

\section{Research Article}

Keywords: Tropical Cyclone, Landsat and SAR data, Damage Assessment, Shock Zonation

Posted Date: October 12th, 2021

DOI: https://doi.org/10.21203/rs.3.rs-962664/v1

License: () (i) This work is licensed under a Creative Commons Attribution 4.0 International License. Read Full License 


\section{Abstract}

The tropical cyclone affects millions of people living in the coastal regions. The changing climate has led to an increased intensity and frequency of cyclones, therefore increasing the damage caused to people, the environment, and property. The Bay of Bengal is most prone to tropical cyclones, which affects Bangladesh and the eastern coastal region of India due to geographical proximity. Hence, a comprehensive understanding of the inundation damage and intensity caused becomes essential to focus the relief efforts on the affected districts. This study identified the shock zone and assessed the inundation associated damage caused by recent cyclone Amphan in the area of Bangladesh and West Bengal in India. The shock zonation was based on the track of cyclones, cyclone wind speed zones, elevation, wind impact potentiality, and agricultural population area. The identification of the affected area was done using integrated Landsat and SAR data, and economic damage cost was assessed using the Asian Development Bank's (ADB) Unit price approach. The total people affected due to inundation are 2.4 million in India and 1.4 million in Bangladesh and the damage totaled up to 5.4 million USD. The results of this study can be used by concerned authorities to identify the shock zones and be used for rapid assessment of the damages.

\section{Introduction}

Tropical cyclones are storms that cause extensive damage to property, disruption of transport and communication networks, loss of human and animal lives, and environmental degradation (Dube et al., 2009; Krapivin et al., 2012; Sahoo and Bhaskaran, 2018, Ying et al., 2014; Needham et al., 2015; Bakkensen and Mendelsohn, 2019). Around the world, around ninety tropical cyclones are formed per year, which causes catastrophic disasters (Murakami et al., 2013). Globally, tropical cyclones have caused the deaths of about 1.9 million people over the past two centuries (Shultz et al., 2005; Hoque et al., 2018). The approximate damage estimated was 26 billion USD each year (Mendelsohn et al., 2012; Hoque et al., 2019). Many studies have predicted an increased number and intensity of tropical cyclones over the years (Mendelsohn et al., 2012; Ranson et al., 2014; Varotsos et al., 2015; Alam and Dominey-Howes, 2015; Walsh et al., 2016; Moon et al., 2019). This increases the risk of impact on coastal communities, animals, environment, and properties (Varotsos and Efstathiou, 2013; Hoque et al., 2019). According to UNISDR's recent report 'Economic loss, poverty, and disasters, 1998-2017 climate-related disaster made over 4.4 billion people homeless, displaced, and injured worldwide. In India and Bangladesh, approximately 5.5\% of the population was directly exposed to disasters in this period. India faced an absolute economic loss of 79.9 billion USD during 1998-2017. World Bank estimates suggest disaster causing over 16 billion USD in total damage in Bangladesh during 1980-2008(UNISDR, 2018).

The Bay of Bengal(BOB) is frequently affected by tropical cyclones. The geographical proximity of Bangladesh and the eastern coast of India to BOB makes the regions highly prone to cyclonic disasters (Islam and Peterson, 2009; Paul et al., 2010; Ahmed et al., 2016; Islam et al., 2016). In the last 100 years, around 17\% of tropical cyclones have made landfall on coastal areas of the Bay of Bengal (Hoque et al., 2019). High-intensity tropical cyclones re-occur frequently causing extensive damage in the coastal region of both countries (Alamand Collins, 2010; Mallick et al., 2017). Further, these coastal regions are highly vulnerable due to large population density, high poverty rates, and the presence of temporary infrastructure. According to Paul and Dutt (2010), more than 1 million people were killed by cyclonic disasters since 1877 in coastal Bangladesh. Further, sea-level rise due to global warming will intensify the impacts of tropical cyclones on people's lives and livelihood across the coastal districts of both India and Bangladesh (Karim and Mimura, 2008; Sarwar, 2013; Abedin et al., 2019).

On 20th May 2020, the tropical cyclone 'Amphan' hit the coast of India and Bangladesh, accompanied by severe storm surges and rainfall (wind speeds up to $195 \mathrm{kmph}$ or $121 \mathrm{mph}$ ). The cyclone caused causalities, killing around 88 people and leaving thousands homeless in India and Bangladesh (Aljazeera, 2020). The cyclone struck at a time when the region had already been ailing with the impact of the COVID-19 pandemic. In such a situation, the relief and recovery measures get further complicated. Therefore, finding the risk zones and estimating the damage is essential to provide an idea about the loss of property, agricultural and livestock, and various primary livelihoods. Some news reports and government organizations published estimated damage for a particular area (Sud and Rajaram, 2020) or specific aspects. Detailed reports on risks and overall damages in the entire cyclonic affected coastal and adjacent districts were not available.

Risk mapping is a fundamental technique to derive spatial information. Risk mapping assesses the impacts of any hazard or Loading [MathJax]/jax/output/CommonHTML/jax.js vironments vulnerable (Pradhan and Lee, 2010; Mohammady et al., 2012; Zare et al., 
2013; Rashid, 2013; Pradhan et al., 2014; Youssef and Al-Kathery, 2015; Dieu et al., 2016; Aghdam et al., 2016). Remote sensing and geospatial technique have been used effectively for mapping risk-prone areas (Yin et al., 2010; Poompavai and Ramalingam, 2013; World Meteorological Organization Communications and Public Affairs Office Final, 2011). MODIS, Sentinel, Landsat data, and Census information are frequently used to understand flood, landslide, earthquake, cyclone impact on land-use land cover and socio-economic situation (Agnihotri et al., 2019; Haraguchi et al., 2019; Jeyaseelan, 2003; Tay et al., 2020; Aksha et al., 2020). A review of existing literature shows the spatial analysis techniques are commonly used for mapping risk (Kunte et al., 2014; Mori and Takemi, 2016; Hoque et al., 2017; Hoque et al., 2018; Karim and Mimura, 2008; Kumar et al., 2011; Dasgupta et al., 2011; Roy and Blaschke, 2013) with the use of multi-criteria based approach being used the most (Poompavai and Ramalingam, 2013; Gao et al., 2014; Quader et al., 2017). The spatial risk assessment model has proven useful in minimizing the loss of life and the socioeconomic impact (Yin et al., 2013; Mahapatra et al., 2015; Masuya et al., 2015), while the current GEOSOM based shock assessment model can assist in mitigation and current impact assessment for a specific event.

Studies related to tropical cyclone risk mapping are done widely, but studies on spatial damage and loss estimation and mapping due to cyclones are very inadequate. An understanding of the socio-economic damages caused by tropical cyclones is important to undertake the proper recovery measures(Ahmed et al., 2016; Joyce et al., 2009). Moreover, spatial loss assessment is crucial for the allocation of resources for agricultural activities, regeneration of jobs, and other socio-economic activities by the funding agencies. There are two popular typologies, direct and indirect estimation. Direct cost considers the immediate cost of any disaster, whereas indirect estimation focuses on the disaster-associated consequences. Rather than distinguishing direct and indirect loss, several studies focus on the assets and output loss approach (Hallegatte, 2015). The Multi-sectorial Input-output model (Haque \& Jahan, 2015), unit cost-based model (GoB, 2008; Roy et al., 2009; Government of Odisha, 2013) are commonly used to estimate the output loss. Significant advancements have been made in the damage assessment framework (Dolman et al., 2018). The availability of real-time satellite data and global socio-economic datasets has significantly improved the damage and loss estimation accuracy. Therefore, our recent study provides deep and elaborate details of damage estimation of the entire flood inundated areas after the cyclone.

This study develops a spatial framework that includes cyclone shock zones and damage and output loss intensity. UN-SPIDER recommended damage estimation practice and unit cost methods were combined to estimates output loss for the entire flood inundated areas caused by cyclone Amphan. This study seeks to analyse the situation of the areas majorly affected by recent inundation and flooding caused by the Amphan cyclone. Firstly, the study assesses the categories of Amphan shock zones to identify potentially exposed areas, rather than following the common risk zonation approach. Secondly, developing a spatial damages assessment framework to account for the economic cost of inundation and flooding on the crop, livestock, and housing units. In this study, the maps produced by risk assessment would be very helpful to identify the spread and intensity of disaster to create the most effective disaster mitigation plan in this area. This understanding of the socio-economic damages caused by tropical cyclones is important for reducing the losses by adopting proper recovery measures(Ahmed et al., 2016; Joyce et al., 2009).

\section{Data}

This study uses socio-economic, disaster, and climate-related data, administrative GIS layers, and satellite data to estimate the cyclone severity and damage intensity. Socio-economic data was used to estimate human exposure to the disaster and the household crisis. Climate data depicts the last $48 \mathrm{hr}$. update of the cyclone event i.e., its track, intensity, and area of influence. The historical disaster records were used to assess the current loss and to compute area-wise disaster damage intensity. Further, GIS layers and remote sensing data served the local to regional level damage and loss information of crop, forest, property, and human life. The database and its preliminary preparation process are illustrated in Table 1.

Loading [MathJax]/jax/output/CommonHTML/jax.js 
Table 1

Details of data used to estimate cyclone shock zones and damage intensity

\begin{tabular}{|c|c|c|c|}
\hline DATA & VARIABLES & SOURCE & DETAILS OF DATA PREPARATION \\
\hline $\begin{array}{l}\text { Bangladesh } \\
\text { Socio- } \\
\text { economic }\end{array}$ & $\begin{array}{l}\text { District total population } 2018, \\
\text { Crop Yield 2018-19; Unit price } \\
\text { of crop and livestock unit } \\
2019-2020 ; \text { Unit price for } \\
\text { property 2018; Poverty rate } \\
2016\end{array}$ & $\begin{array}{l}\text { Bangladesh Bureau of Statistics; } \\
\text { Yearbook of Agricultural } \\
\text { Statistics 2019; Department of } \\
\text { Agricultural Marketing; Food for } \\
\text { Nation, Ministry of Agriculture; } \\
\text { HIES } 2016\end{array}$ & $\begin{array}{l}\text { - Official population data is used to } \\
\text { validate the WorldPop population grid } \\
\text { data } \\
\text { - Crop yield, livestock product/unit, and } \\
\text { unit price data used to estimate the } \\
\text { output value/unit crop and livestock } \\
\text { - Standard property reconstruction } \\
\text { price/unit data used to estimate the total } \\
\text { cost of reconstruction }\end{array}$ \\
\hline $\begin{array}{l}\text { IndiaSocio- } \\
\text { economic }\end{array}$ & $\begin{array}{l}\text { District total population 2011, } \\
\text { Crop Yield; Unit price of crop } \\
\text { and livestock 2019-20; Unit } \\
\text { price for property 2018-19; } \\
\text { the Poverty rate }\end{array}$ & $\begin{array}{l}\text { Census of India 2011; DACNET; } \\
\text { Agmarknet; NABARD;PMAY-G; } \\
\text { Poverty Grid, Livemint }\end{array}$ & $\begin{array}{l}\text { - Official population data is used to } \\
\text { validate the World Pop population grid } \\
\text { data } \\
\text { - Crop yield, total livestock, and unit price } \\
\text { data were used to estimate the output } \\
\text { value/unit crop and livestock } \\
\text { - Standard property reconstruction } \\
\text { price/unit data used to estimate the total } \\
\text { cost of reconstruction }\end{array}$ \\
\hline GIS layers & $\begin{array}{l}\text { Previous cyclone path; global } \\
\text { exposure (low-income group) } \\
\text { 2015; Bangladesh district } \\
\text { administrative boundary from } \\
\text { HDX and } \\
\text { Indian district boundary } 2011 \\
\text { from Datameet (open } \\
\text { platform); FAO Livestock } \\
\text { population 2010; GHSL 2014; } \\
\text { Population grid 2020 }\end{array}$ & $\begin{array}{l}\text { Humanitarian Data Exchange } \\
\text { (HDX);Data meet; FAO } \\
\text { agricultural statistics; European } \\
\text { commission; WorldPop }\end{array}$ & $\begin{array}{l}\text { - History of previous cyclone track data is } \\
\text { valuable to understand the regional risk } \\
\text { from the cyclone events } \\
\text { - Spatial estimated population dataset is } \\
\text { useful to estimate the current population } \\
\text { under threats } \\
\text { - The reliability of the population spatial } \\
\text { dataset is checked using } 2011 \text { as a } \\
\text { reference year. } \\
\text { - Total low-income rural population data } \\
\text { is extracted from the global human } \\
\text { exposure dataset } 2015 \text {. } \\
\text { - The } 2010 \text { man-animal proportion is } \\
\text { used to compute the livestock population } \\
\text { in } 2020 \text {. } \\
\text { - Built-up grid data is used to validate the } \\
\text { household unit for the year } 2014 \text {. } \\
\text { - WorldPop population grid data is used } \\
\text { to estimation the inundation impact on } \\
\text { human life }\end{array}$ \\
\hline $\begin{array}{l}\text { Sentinel-1C- } \\
\text { band, and } \\
\text { Landsat 8, } \\
\text { SRTM DEM } \\
\text { data }\end{array}$ & $\begin{array}{l}\text { Flood inundation extent map } \\
\text { on 1st May } 2020 \text { and 22nd } \\
\text { May 2020; LULC based } \\
\text { standing cropland, built-up, } \\
\text { flood inundation 4th May } \\
\text { 2020; Elevation }\end{array}$ & LANCE; USGS & $\begin{array}{l}\text { - SAR, Landsat } 8 \text { data, and random forest } \\
\text { classification scheme is used to prepare } \\
\text { the LULC map for the year May } 2020 \text { in } \\
\text { the Google earth engine. } \\
\text { - DEM elevation data is used to validate } \\
\text { the inundated area }\end{array}$ \\
\hline Climate & CycloneAmphan track & IMD and BMD & $\begin{array}{l}\text { - Details track of Amphan } 2020 \text { is used to } \\
\text { demarcate the risk zones based on wind } \\
\text { speed: High risk [wind speed: Above } \\
120 \mathrm{kmph} \text { ], medium risk [wind speed: } 90- \\
120 \mathrm{kmph}] \text {, low risk zone [Below } \\
90 \mathrm{kmph} \text { ). }\end{array}$ \\
\hline
\end{tabular}




\begin{tabular}{|llll|}
\hline DATA & VARIABLES & SOURCE & DETAILS OF DATA PREPARATION \\
\hline Disaster & $\begin{array}{l}\text { Category wise damage and } \\
\text { loss from previous cyclones }\end{array}$ & $\begin{array}{l}\text { Government reports on Feni, Alia } \\
\text { andPhalin, Sidr; Bangladesh } \\
\text { Disaster Report 2009-2014; } \\
\text { Reliable online media }\end{array}$ & $\begin{array}{l}\text { ・ Reviews on previous cyclones, its } \\
\text { intensity,damage, and loss amount are } \\
\text { collected; Current media gross damage } \\
\text { information is used to validate our } \\
\text { estimated information. }\end{array}$ \\
\hline
\end{tabular}

\section{Methods}

The study was carried out in four major steps. First, shock zones were defined using the cyclone characteristics and sociodemographic situation shock zones. Second, using remote sensing and GIS tools LULC and flood-affected areas were demarcated. Third, the impacts of inundation were estimated using LULC, inundation area, population, and poverty situation. Finally, cyclone shock zones and their associated cost are estimated to understand the association between cyclone intensity and damage. Detail workflow of these steps is illustrated in Figure 1.

\subsection{LULC and flood mapping}

Medium resolution optical $(30 \mathrm{~m} \times 30 \mathrm{~m}$ ) Landsat 8 data along with $10 \mathrm{~m}$ resolution Sentinel-1 C-band GRD data dated 4th May 2020 was used. A combination of SAR and optical data is used to reduce the chances of misclassification. The present study follows the Anderson et al., (1976) LULC classification scheme to prepare the LULC data in the Google Earth Engine (GEE). A Random Forest (RF) algorithm is used for the large area, because of its high accuracy(Abdullah et al., 2019). Six broad spectral classes were used, i.e., Built-up, Open land, Cropland, Vegetation, Sand, and Water bodies using 100 training pixels for each class. The overall accuracy of the LULC data was computed to be $91 \%$ and the Kappa coefficient was $89 \%$.

Inundation change analysis performed in the GEE Sentinel-1C-band GRD imagery with VV, VH polarization, and 'DESCENDING' pass direction for the dates 4th May 2020 and 22nd May 2020 was used for pre and post-inundation situation (Uddin et al., 2019). In the GEE, all the data is pre-processed (i.e., noise removal, radiometric correction, and terrain correction, and finally, backscatter scattering to decibel conversion). The intensity of change per pixel was estimated by dividing after flood mosaic with before flood mosaic. A binary flood layer was prepared using a threshold of 1.25, where values above 1.25 were assigned a score of 1 and all other pixels are assigned a score of 0 .

Table 2

Grid level sector-wise loss estimation

\begin{tabular}{|c|c|}
\hline Sectors & Bangladesh \\
\hline $\begin{array}{l}\text { Croploss } \\
\text { estimation }\end{array}$ & $\begin{array}{l}\text { CropCost }=\text { Innundationaffectedcroppedarea } * \sum\left(\text { Yield }_{i j} * \text { unitprice }_{i j}\right) \\
\text { Where i represent district and j represents crop types }\end{array}$ \\
\hline $\begin{array}{l}\text { Livestock } \\
\text { loss } \\
\text { estimation }\end{array}$ & 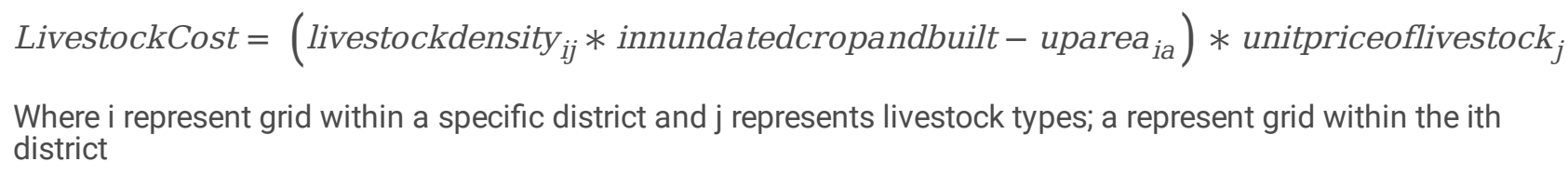 \\
\hline $\begin{array}{l}\text { Housing } \\
\text { loss } \\
\text { estimation }\end{array}$ & $\begin{array}{l}\text { HousingCost }=\left(\frac{\text { innundatedbuilt-uparea }_{i}}{\text { standardreconstructionarea }}\right) * \text { unitpriceofpartialreconstruction }_{\text {national }} \\
\text { Where i represent grid within a specific district }\end{array}$ \\
\hline Population & Low-income rural population around the flooded $(<1 \mathrm{~km})$ was estimated for each grid \\
\hline
\end{tabular}

\subsection{Damage and loss estimation}

Details on average damage and loss pattern of cyclone events were compiled from different reports. Based on the data Loading [MathJax]/jax/output/CommonHTML/jax.js the housing, crop, and livestock sectors including human life. Damage and loss 
quantity vary significantly between rural and urban areas. The damage assessment for the infrastructure and forestry sectors was not attempted due to inconsistencies in the media report and the absence of reliable spatial data.

This study followed two steps to estimate the loss value which is in a comparable form. Firstly, inundation affected cropland, livestock, and housing loss area was estimated using the $5 \mathrm{~km} \times 5 \mathrm{~km}$ grid. Secondly, inundated cropland and the built-up area within each grid was multiplied with the unit price of the crop, livestock, and housing. The values are converted into USD using country-specific exchange rate. Details steps are illustrated in Table 2.The total cyclone damage and loss amount are estimated for each cyclone shock zone and district.

\subsection{Amphan and poverty severity}

Grid wise population data and flood-affected areas were intersected to estimate population exposure to inundation. Also, low income rural and urban population from the global exposure dataset 2014 were used to estimate the district-wise poor population share. Next, the association between district-level poverty rate and damage intensity was computed to understand the cyclone induced poverty. Further, food accessibility and total risk information were combined to assess the severity of poverty. This estimation identifies the areas which require urgent relief and the approximate amount of monetary support needed.

\subsection{Amphan cyclone severity zone}

Cyclone wind speed zones, elevation, wind impact, distance from cropland and vegetation, business loss, and agricultural population area was used to prepare Amphan severity zones. All these variables were normalized such that higher values indicate high severity and lower value indicate low severity. These zones are then intersected with the damage data to understand the association between cyclone shocks intensity and damage intensity.

Four zones were extracted using GeoSOM Ward's criterion-based 'Contiguity- constrained hierarchical clustering' process, available in the SPAWNN toolkit algorithm (Hagenauer and Helbich, 2016). The spatial clustering approach is a two-step process to define the Best Matching Unit (BMU). Firstly, based on the input dataset i.e., wind speed, distance from the cyclone track, elevation, and proportion of rural area closest neurons are identified. Secondly, a distance criterion is applied to the identified closest neurons. This study used radius $=1$ to reduce the spatial dependencies in BMU. Each input variable and its BMU structure are presented in a hexagonal space. This spatial clustering is based on self-organising neural network techniques which are useful for its information extraction capability from the large spatial dataset.

\section{Results}

\subsection{Bay of Bengal and tropical cyclones}

The coastline of India and Bangladesh is highly vulnerable to tropical cyclones. Between 1877 and 2016, 525 cyclonic storms were recorded (Bandopadhay et al., 2018). The recorded trend shows that the yearly incidence of the cyclone has increased by about $35.9 \%$ during the past century. The maximum wind speed has increased by $18.5 \%$ in the past century, with a rapid rise after 1960. The median landfall locations of the tropical cyclone are distributed in a broad arc from the central coastline of Odisha to the Western coastline of Bangladesh. The median landfall has shifted over the years. Median landfalls were in Odisha from 1877 to 1920, the border of Odisha and West Bengal from 1921 to 1960, and the border of West Bengal and Bangladesh from 1961 to 2016. Between 1981 and 2000 the cyclone intensities were the highest at West Bengal and Northern Orissa with 32-37 strikes per year. Bandyopadhyay et al. (2018). This intensity declines incrementally in both the direction. While the highest mean speed of 5863 knots occurred in the eastern coastal area of Bangladesh.Since2000 over 180 cyclones hit this coastal area. In general, the cyclones occur in the months of April-June and September-November. According Indian Meteorological Department during 20002019 cyclone intensification probability from depression to the severe cyclone is quite high in the month of April (60\%), May (45\%), November (40\%) followed by December and October. Cyclones which developed in the Bay of Bengal between 2000-2019 moved towards two-dominant directions, one is towards north-west (Odisha, Andhra Pradesh, and central India), and the other move towards north-east (West Bengal and Bangladesh), as illustrated in Figure 2.

Loading [MathJax]/jax/output/CommonHTML/jax.js 
Cyclonic storms occur frequently over the regions of the eastern coast of India and Bangladesh. Since, 2007, 1-2 cyclonic storms occur each year. The wind speed ranges from $75 \mathrm{~km} / \mathrm{hr}$ to $260 \mathrm{~km} / \mathrm{hr}$, with half of the cyclones falling in the super cyclonic storm or extremely severe cyclonic storm range. The overall losses depend upon the intensity of the cyclone and the geographic region where it hits (Table 3 ).

Amphan made landfall on the 20th of May affecting districts in the states of Odisha, West Bengal in India, and few districts in Bangladesh. This study considers the areas lying around $200 \mathrm{Kms}$ from the path of the cyclone. The area of interest includes 26 districts in Bangladesh, 12 districts from West Bengal, and 1 district of Odisha, India. The total track length of the cyclone Amphan was $1765 \mathrm{Km}$. It crossed the West Bengal coast as an extremely severe cyclonic storm with a speed of 185-190 Kmh. Rapid intensification was observed after landfall over the West Bengal coast, after which it moved north-east into Bangladesh as a severe cyclonic storm. It weakened into a deep depression as it moved further north-east. It causes storm surge with a height of around 4.5-5 meters and heavy rainfall in the coastal area of Odisha, West Bengal, and Bangladesh.

Table 3

Estimated damages and wind speed of severe cyclones which occurred in the 21 st century in coastal areas of India and Bangladesh

\begin{tabular}{|c|c|c|c|}
\hline Cyclone Name & Date of occurrence & Wind speed $(\mathrm{km} / \mathrm{hr})$ & Damage/Losses [USD] \\
\hline Akash & 2007; May & 115 & 982 million \\
\hline Sidr & 2007; November & 260 & 2.31 billion \\
\hline Nargis & 2008; October & 165 & 12.9 billion \\
\hline Aila & 2009; May & 120 & 1 billion \\
\hline Vivaru & 2013; May & 85 & 35 million \\
\hline Phailin & 2013; October & 260 & 4.26 billion \\
\hline Hudhud & 2014; October & 215 & 3.58 billion \\
\hline Komen & 2015; July & 75 & 18.1 million \\
\hline Roanu & 2016; May & 100 & 31.8 million \\
\hline Mora & 2017; May & 110 & 5.58 million \\
\hline Fani & 2019; May & 215 & 8.1 billion \\
\hline Bulbul & 2019; November & 140 & 3.37 billion \\
\hline Amphan & 2020; May & 260 & 13.6 billion \\
\hline \multicolumn{4}{|c|}{ 4.2Damage estimation } \\
\hline \multicolumn{4}{|c|}{$\begin{array}{l}\text { Amphan cyclone caused inundation, which severely affected the cropland, livestock, and property in } 18 \text { districts of India and } \\
26 \text { districts in Bangladesh. The districts of Purba Medinipur, Nadia, South } 24 \text { Pargana, and in Bangladesh \&Barisal, Phirojpur, } \\
\text { Bagerhat, Gopalganj, Meherpur, Chuadanga, Kushtia, Natore, Rajshahi, Bogra, and Gaibandhawere badly affected due to } \\
\text { severe rainfall and storm surge. Inundation caused total damage of around } 5.4 \text { billion USD in Bangladesh and India, which is } \\
0.03 \% \text { and } 0.23 \% \text { of the state GDP of Bangladesh and India, respectively(Table 4). The total damage amount is expected to } \\
\text { increase exceptionally if all sectors are included in the estimation. }\end{array}$} \\
\hline
\end{tabular}


Table 4

Estimated damage in Bangladesh and India

\begin{tabular}{|c|c|c|c|c|c|c|c|}
\hline \multirow[t]{2}{*}{ Sector } & \multirow[t]{2}{*}{ Item } & \multicolumn{3}{|c|}{ Bangladesh } & \multicolumn{3}{|l|}{ India } \\
\hline & & No of unit & Cost (USD) & GDP share & No of unit & Cost (USD) & GDP share \\
\hline Crop & Rice & 61074 ha & 37087154 & $0.01 \%$ & 107215 ha & 287684745 & $0.15 \%$ \\
\hline \multirow[t]{6}{*}{ Livestock } & Buffalo & 401 & 337136 & & 30 & 26109 & \\
\hline & Cattle & 2395 & 2011731 & & 1593 & 1375830 & \\
\hline & Sheep & 89 & 10660 & & 74 & 6257 & \\
\hline & Goat & 4338 & 520496 & & 1528 & 129208 & \\
\hline & Poultry & 47386 & 162048 & & 11264 & 42117 & \\
\hline & Total & 54609 & 3042071 & $0.0009 \%$ & 14489 & 1508166 & $0.0008 \%$ \\
\hline Housing & Total & 67580 & 60817302 & $0.02 \%$ & 141271 & 150168736 & $0.08 \%$ \\
\hline \multicolumn{2}{|l|}{ Total cost } & \multicolumn{2}{|c|}{$\$ 10,09,46,527$} & $0.03 \%$ & \multicolumn{2}{|c|}{$\$ 43,93,61,646$} & $0.23 \%$ \\
\hline \multicolumn{2}{|c|}{ GDP 2019-20 (current price) } & \multicolumn{3}{|c|}{$\$ 3,31,56,01,37,539$} & \multicolumn{3}{|c|}{$\$ 1,91,91,68,10,631$} \\
\hline
\end{tabular}

\subsubsection{Crop damage}

The agriculture and animal husbandry sectors are a major contributor to the State Gross Domestic Product of West Bengal. Almost 22\% GSVA came from the agriculture, livestock, fisheries, and forestry sectors in the year 2017-18. According to the Census of India 2011, more than $68 \%$ of people depended on the agricultural sector and around $16 \%$ of people (cultivators and agricultural labour) were directly engaged with this sector, which is spread over $5.25 \mathrm{mha}(60 \%)$ area. Paddy and Pulses are the dominant crops followed by Jute, Maize, Wheat, Potato, Sugarcane, Til, Mung, Vegetables. In the months of April-June Aus paddy, pulses, vegetables, and fruits (mango).

In Bangladesh, more than $10 \%$ of GDP came from the agriculture, livestock, fisheries, and forestry sectors in the financial year 2019. This sector manages to feed more than $40 \%$ of the labour force. More than $83 \%$ of households in the country live in rural areas and are dependent on agricultural and allied sectors. Agriculture is still the dominant activity in the country with 8 Mha net cropped area (54\%). Paddy is the major crop ( $77 \%)$, followed by pulses $(2.8 \%)$, oilseed $(2.78 \%)$, spices and condiments $(2.53 \%)$, and vegetable $(1.27 \%)$.

Cyclone Amphan severely affected the agricultural sector in India and Bangladesh. Severe rainfall caused heavy crop damage. A total of 0.11 Mha and 0.06 Mha cropland was severely affected due to inundation in the districts of West Bengal, and Bangladesh respectively, which was under kharif crops (Figure 4). Mostly rice, pulses, vegetation, and mango fruit were affected in the districts of West Bengal, whereas largely paddy cultivation was affected in Gopalganj (4.7 million USD), Jassore (4.4 million) and Jhenaidah (3.8 million USD) districts of Bangladesh due to heavy rainfall. The loss in monetary terms was more than 288 million USD in West Bengal and 37 million USDin Bangladesh, which is around $0.15 \%$ and $0.01 \%$ of state GDP respectively. Purba Midnapur (146.6 million USD), Paschim Midnapur (55 million USD), and Howrah (17.9 million USD) were the worst affected districts in India.

\subsubsection{Livestock damage}

A large proportion of poor rural households are directly or indirectly dependent on the livestock product as a food source and household income in West Bengal, India, and Bangladesh. The livestock sector is an important contributor to the West Bengal state economy with a share of $4.41 \%$ of the state domestic product. Bangladesh's rural livestock economy contributes $1.43 \%$ of GDP.. 
The recent cyclone caused extensive damage to the livestock economy in West Bengal and Bangladesh. Livestock death has not been considered as this information was not available. This study assumed that flooded areas were more prone to livestock deaths; therefore damage associated with the inundation was estimated here. In West Bengal, a total of 3.2 thousand livestock and 11.3 thousand poultry units were affected due to the submergence of built-up and crop area, whereas 7.2 thousand livestock and 47.4 thousand poultry unit were affected in Bangladesh. Amphan flood caused around 3.04 million USD livestock damage in Bangladesh and 1.51 million USD in West Bengal, India. Purba Medinipur (0.59 million USD), Paschim Medinipur (0.30 million USD), South 24 Parganas (0.23 million USD), and Howrah (0.22 million USD) has been severely affected in West Bengal. Jhalokati (0.59 million USD), Barguna (0.54 million USD), and Bagerhat ( 0.46 million USD) districts have been severely affected due to flooding in Bangladesh (Figure 5).

\subsubsection{Housing damage}

Cyclone Amphan caused extensive damage to the housing units. Both kutcha and semi-pucca houses were affected due to flooding and associated cyclonic wind. The assessment considered household units that were submerged underwater for around 3-4 days after the cyclone, as spatial information on affected kutcha and pucca structures is unavailable. Therefore, this study assumes that both kutcha and pucca structures were partially damaged due to heavy rainfall and storm surge. Almost 0.2 million housing units were affected due to recent inundation in West Bengal, where districts Purba Medinipur, Hoogly, Howrah, S. 24 Parganas, and Paschim Medinipur were severely affected. In Bangladesh, approximately0.9 million housing units were severely affected due to flooding.

The partia Icost for reconstruction of houses in West Bengal amounted to 150.17 million USD and 60.8 million USD in Bangladesh. Housing units in Purba Medinipur, S 24 Parganas, N 24 Parganas in India, Gaibandha, Phirojpur, Natore, Khustia, and Bogradistrict were badly affected (Figure 6).

\subsection{Impact on low-income household}

Disaster damage has a strong positive relationship with the cancelation of poverty eradication. Bangladesh is still considered at high risk for disaster-induced poverty (ODI, 2013). The situation of Bangladesh is extremely critical as every year disaster-related damages increase the poverty incidence. A high proportion of the low-income rural populations, high disaster frequency, and spread of settlement over the low-lying areas are the major cause of high disaster damage. The situation in West Bengal is different from Bangladesh as the high-density population, physical setting and unplanned development activity increase the damage intensity and resultant poverty rate. Even though the disaster early warning has helped in reducing the degree of disaster losses, the displacement due to disaster and loss of livelihood loss due to disaster is increasing.

Recent inundation in Bangladesh directly affected 1.4 million people, which is almost 3 percent of the total population in the study region. Jhalokati (28\% population), Phirojpur (23\%), Bagerhat (11\%), Barguna (11\%), Barisal (9\%) and Gopalganj (8\%) districts are extremely affected due to the inundation. Among these districts a high number of poor populations accounted in Phirojpur (17.6\%) are poor followed by Gopalganj (15.5\%), Bagerhat (14\%), Barisal (13.6\%), and Barguna (12\%). Bagerhat are in the most critical state in term of poverty rate and damage share (11.8\%) followed by Barisal (19.6\%), Gopalganj (10.7\%), Phirojpur (7\%) and Barguna (7\%) (Figure 7). Although the number of people affected in the Patuakhali is small, but the poverty rate (24.4\%) and damage share (8\%) are significantly high. Similarly, a large number of poor populations are affected in India. A total of 2.3 million people is directly affected due to heavy rainfall and inundation damage. Purba Medinipur is the worst affected district in West Bengal (19\% population), followed Howrah (10\%), Paschim Medinipur (5\%) and Balasore (7\%) district of Odisha. The poverty rate of Purba Medinipur, Paschim Medinipur, Howrah and Baleshwar are $17.7 \%, 23 \%, 14.3 \%$ and $33 \%$ respectively. Paschim Medinipur are in the most critical state in term of poverty rate and damage share (15.6\%) followed by Purba Medinipur (52\%) and S 24 Parganas (6\%) (Figure 8). The share of the poor population in Bangladesh is quite high as compare to India, therefore Amphan damage intensity has made a severe crisis in Bangladesh.

\subsection{Cyclone shock zones}

The shock zones define the varied vulnerability (Figure 8). The districts were clustered into four shock zones using the variableswind speed, distance from the cyclone track, elevation, and proportion of the rural area. The highest shock zone lies along the Loading [MathJax]/jax/output/CommonHTML/jax.js

Page $9 / 22$ 
cyclone track, experienced the highest wind speed, was prone to storm surge due to low elevation, and had a greater proportion of rural areas (Table 5).

In India, the wind speed experienced was highest for Zone I, followed by Zone II, Zone III, and lastly Zone IV. The wind speed showed a declining trend from Southeast to North West. Zone I in Bangladesh faced the greatest wind speed, followed by Zone III, Zone IV, and Zone II respectively. Wind speed showed a decline from west to east and from south to north in Bangladesh.

The cyclone travelled from south-west to north-east. Hence, the north-west and south-east area of interest lie farthest from the cyclone track. In India, Zone I and II and in Bangladesh Zone IV and Zone I were closest to the path of the cyclone.

The lower elevation areas have the highest chance of being affected due to cyclone, experiencing flood and storm surges. In India, for elevation Zone I lies at the lowest elevation, followed by zone II and zone III respectively. In Bangladesh, Zone I had the lowest elevation followed closely by zone 3 and zone II.

Rural tracts have greater vulnerability owing to the damage caused to agricultural land, livestock and temporary infrastructures such as mud and thatched houses. Bangladesh is predominantly rural, hence more vulnerable as compared to India

Table 5

Summary of cyclone Amphan shock zones

\begin{tabular}{|c|c|c|c|c|c|c|c|c|}
\hline \multirow[t]{2}{*}{ RISK ZONES } & \multirow{2}{*}{\multicolumn{2}{|c|}{ WIND SPEED }} & \multirow{2}{*}{\multicolumn{2}{|c|}{$\begin{array}{l}\text { DISTANCE } \\
\text { FROM TRACK }\end{array}$}} & \multirow{2}{*}{\multicolumn{2}{|c|}{$\begin{array}{l}\text { SHARE OF } \\
\text { RURAL AREA }\end{array}$}} & \multirow{2}{*}{\multicolumn{2}{|c|}{ ELEVATION }} \\
\hline & & & & & & & & \\
\hline & MAXIMUM & \multirow{3}{*}{$\begin{array}{l}\text { PARTIAL } \\
\text { AREA }\end{array}$} & & \multirow[t]{3}{*}{$\begin{array}{l}\text { PARTIAL } \\
\text { AREA }\end{array}$} & MAXIMUM & \multirow[t]{3}{*}{$\begin{array}{l}\text { PARTIAL } \\
\text { AREA }\end{array}$} & MAXIMUM & \multirow[t]{3}{*}{$\begin{array}{l}\text { PARTIAL } \\
\text { AREA }\end{array}$} \\
\hline $\begin{array}{l}\text { WEST } \\
\text { BENGAL }\end{array}$ & AREA & & AREA & & AREA & & AREA & \\
\hline \multicolumn{5}{|l|}{ AND ODISHA } & & & & \\
\hline ZONE I & Very High & & Very Close & Close & $\begin{array}{l}\text { Lowest to } \\
\text { Low }\end{array}$ & $\begin{array}{l}\text { Medium } \\
\text { to High }\end{array}$ & $\begin{array}{l}\text { Lowest to } \\
\text { Low }\end{array}$ & \\
\hline ZONE II & High & Medium & Very Close & & $\begin{array}{l}\text { Lowest to } \\
\text { Low }\end{array}$ & & Low & Lowest \\
\hline ZONE III & Medium & $\begin{array}{l}\text { High and } \\
\text { Low }\end{array}$ & $\begin{array}{l}\text { Close to } \\
\text { Medium }\end{array}$ & Very Close & $\begin{array}{l}\text { Lowest to } \\
\text { Low }\end{array}$ & & Low & \\
\hline ZONE IV & Very Low & Low & $\begin{array}{l}\text { Farthest to } \\
\text { Far }\end{array}$ & & $\begin{array}{l}\text { Lowest to } \\
\text { Low }\end{array}$ & $\begin{array}{l}\text { Medium } \\
\text { to High }\end{array}$ & Very High & High \\
\hline \multicolumn{9}{|l|}{ BANGLADESH } \\
\hline ZONE I & $\begin{array}{l}\text { Very High } \\
\text { to High }\end{array}$ & & Very Close & Close & Highest & & Lowest & Low \\
\hline ZONE II & Low & Very low & $\begin{array}{l}\text { Farthest to } \\
\text { far }\end{array}$ & & Highest & & Lowest & $\begin{array}{l}\text { Medium } \\
\text { to Low }\end{array}$ \\
\hline ZONE III & Medium & High & $\begin{array}{l}\text { Far to } \\
\text { Medium }\end{array}$ & $\begin{array}{l}\text { Close to } \\
\text { Medium }\end{array}$ & Highest & & Low & $\begin{array}{l}\text { Medium } \\
\text { to Low }\end{array}$ \\
\hline ZONE IV & Low & Medium & Very Close & & Highest & & Highest & \\
\hline \multicolumn{9}{|c|}{$\begin{array}{l}\text { Wind score: 0.0-0.2 (very low), 0.2-0.4 (low), 0.4-0.6 (medium), 0.6-0.8 (high), 0.8-1.0 (very high); Track proximity: 0.0-0.2 } \\
\text { (farthest), 0.2-0.4 (far), 0.4-0.6 (medium), 0.6-0.8 (close), 0.8-1.0 (very close); Proportion of rural population: 0-20 (lowest rural), } \\
20-40 \text { (low rural), 20-60 (Medium rural), 60-80 (High rural), 80-100 (Highest rural); Elevation: 0.0-0.2 (Highest); 0.2-0.4 (high); } \\
0.4-0.6 \text { (medium);0.6-0.8 (low); 0.8-1.0 (lowest) }\end{array}$} \\
\hline
\end{tabular}


Table 6

Cyclone shock zones and damage intensity

\begin{tabular}{|lllllll|}
\hline Country & Sector & \multicolumn{3}{l}{ Shock zones wise damage share (\%) } & \multirow{2}{*}{ Total } \\
\cline { 3 - 6 } & & I & II & III & IV & \\
\hline \multirow{2}{*}{ Bangladesh } & Crop & 1.92 & 0.42 & 1.76 & 2.76 & 6.86 \\
\cline { 2 - 6 } & Livestock & 0.04 & 0.40 & 0.11 & 0.02 & 0.56 \\
\cline { 2 - 6 } & Housing & 0.88 & 6.93 & 2.72 & 0.72 & 11.26 \\
\hline \multirow{2}{*}{ India } & Crop & 30.87 & 12.41 & 9.11 & 0.86 & 53.24 \\
\cline { 2 - 6 } & Livestock & 0.20 & 0.05 & 0.02 & 0.01 & 0.28 \\
\cline { 2 - 6 } Total & Housing & 22.86 & 3.41 & 1.45 & 0.07 & 27.79 \\
\hline
\end{tabular}

Zone I for West Bengal and Zone II for Bangladesh was the most affected by Amphan(Table 6).Zone I lied directly in the path of the cyclone, hence experienced high wind speed. Zone I (India) had the lowest elevation, hence making the area highly vulnerable to the damage caused by the cyclone. Zone II (Bangladesh) was not close to the cyclone track but near to the coast and the entire region is in low-lying area, hence experienced the highest storm surge, rainfall, and high wind speed.

\section{Discussion And Conclusion}

Spatial risk zonation is commonly used to identify the exposed area to certain disasters. In general, historical data and large heterogeneous actors are incorporated into the risk assessment models. Based on the exposed area measurement approach this study demarcates four shock zones based on elevation, distance from cyclone track, wind speed, and rural area share based on GEOSOM clustering. These zones explain the degree of initial shock that Amphan created over India and Bangladesh. Extracted shock zones are useful to understand the potential exposed area and damage intensity. This study used these zones to estimate the inundation and flood-related damage caused by the cyclone. Estimation suggested that the cyclone intensity and inundation damage was not mutually inclusive. The northern and eastern parts of the study area did not face severe wind and were quite far from the eye of the cyclone, but inundation damage was still high. Physical setting and rainfall intensity caused huge damage within the $200 \mathrm{~km}$ radius. A sudden weakening of the translation speed of Amphan caused an increase in rainfall and inundation damage in Bangladesh, as also noticed in Kossain's (2018) findings. These generalized climatic risk micro-zonation and ranking mechanisms can induce event-specific bias to future management plans.

The spatial damage assessment framework integrated UN-SPIDER SAR-based flood damage estimation and Asian Development Bank's (ADB) unit price approach to assess the economic loss. All these types of damage and loss estimation framework largely underestimate the actual cost. However, the current spatial approach is more useful and cost-effective to identify the worst affected location and damage intensity more clearly. Only the inundation associated with economic loss was captured. News reports and govt. organizations published estimated total damage, but a detailed report on Amphan inundation impact was not available for the entire cyclonic affected coastal and adjacent districts.According to government sources the total estimated damages of Amphan is 132 million USD in Bangladesh and PCD Global estimates show 12.4 billion USD in India, whereas our estimation suggests only flood and inundation caused total damage of 5.4 billion USD. Flood and inundation caused $31 \%$ of total damage in India, $7 \%$ in Bangladesh. If we considered the global average flood impact, up to average of 5.5\% people will be expected to fall below the poverty line in Bangladesh and West Bengal.

This framework is more reliable and fit for flood damage assessment but can be usedto estimate damage and loss for all types of natural disasters if the required information is available. However, the current approach has several limitations such as Grid level assessment $(5 \mathrm{~km} \times 5 \mathrm{Km})$, partial flood damage assessment, which leads to gross generalization due to unit cost approach, and classification error. First, in general, the grid-based estimation is sometimes unable to provide high spatial accuracy, which can also increase the underestimation error. However, large coverage areas and different sources of information can be easily

Loading [MathJax]/jax/output/CommonHTML/jax.js

Page $11 / 22$ 
integrated using this approach. Second, partial estimation of inundation damage is captured through the above methodology as data on types of standing crops was not available. Therefore, district-level gross estimates were apportioned to the grid level. Similarly, damaged kutcha and pucca household locations were not available, even the degree of damage information was not available. Hence, partial damage cost is uniformly applied to estimate the property damage. Third, the unit cost approach introduces large generalization. Even though the previous estimates largely follow this approach, no other standard universal tools are available. Fourth, some LULC classification errors and flood detection errors are unavoidable, although these are minimized using rigorous accuracy checks and post-classification data standardization.

Even though the spatial damage estimation has always been a subject to underestimation as it only captures the material cost, hence underestimating the actual economic cost. The spatial approach is still useful as it is suitable to assess the pattern and degree of damage and identifies the worst affected location. This spatial damage estimate framework is indispensable to improve the relief and support mechanism. The damage estimation is essential to channelize the resources and funds to the affected people and proper locations. This method is quite cost-effective and efficient as large-scale spatial datasets as tools and techniques are readily available. Remote sensing and GIS technology can be used to for a rapid estimation of the aftereffect of any disaster event possible. This research adds to the research by developing a spatial direct damage estimation framework using freely available spatial dataset.

\section{Declarations}

\section{Ethical statement}

We confirm that any aspect of the work covered in this manuscript that has involved human patients has been conducted with the ethical approval of all relevant bodies and that such approvals are acknowledged within the manuscript.

Declared by Authors-

1. Medha, Centre for the Study of Regional Development, Jawaharlal Nehru University, New Delhi, India, medha.1395@gmail.com

2. Biswajit Mondal, Centre for the Study of Regional Development, Jawaharlal Nehru University, New Delhi, India, b.mondol.gis@gmail.com

3. Gour Doloi, Assistant Professor (SACT), Panskura Banamali College, gourdolui@gmail.com

Competing interests: The authors declare no competing interests.

\section{References}

1. ABC Report, (2020). Cyclone Amphan slams into India and Bangladesh, evacuations complicated by coronavirus. $A B C$ News. https://www.abc.net.au/news/2020-05-20/super-cyclone-amphan-india-bangladesh-brace-for-storm-surges/12266496

2. Abedin, M.A., Collins, A.E., Habiba, U., Shaw, R., 2019. Climate change, water scarcity, and health adaptation in southwestern coastal Bangladesh. International Journal of Disaster Risk Science 10 (1), 28-42.

3. Aghdam, I.N., Varzandeh, M.H.M., Pradhan, B., 2016. Landslide susceptibility mappingusing an ensemble statistical index (Wi) and adaptive neuro-fuzzy inference system(ANFIS) model at Alborz Mountains (Iran). Environ. Earth Sci. 75 (7), 553.

4. Agnihotri, A. K., Ohri, A., Gaur, S., Shivam, Das, N., \& Mishra, S. (2019). Flood inundation mapping and monitoring using SAR data and its impact on Ramganga River in Ganga basin. Environmental Monitoring and Assessment, 191(12). https://doi.org/10.1007/s10661-019-7903-4

5. Ahmed, B., Kelman, I., Fehr, H., Saha, M., 2016. Community resilience to cyclone disasters in coastal Bangladesh. Sustainability 8 (8), 805.

6. Aksha, S. K., Resler, L. M., Juran, L., \& Carstensen, L. W. (2020). A geospatial analysis of multi-hazard risk in Dharan, Nepal. Geomatics, Natural Hazards and Risk, 11(1), 88-111. https://doi.org/10.1080/19475705.2019.1710580

Loading [MathJax]/jax/output/CommonHTML/jax.js 
7. Alam, E., Collins, A.E., 2010. Cyclone disaster vulnerability and response experiences in coastal Bangladesh. Disasters 34 (4), 931-954.

8. Alam, E., Dominey-Howes, D., 2015. A new catalogue of tropical cyclones of the northern Bay of Bengal and the distribution and effects of selected landfalling events in Bangladesh. Int. J. Climatol. 35 (6), 801-835.

9. Bakkensen, L.A., Mendelsohn, R.O., 2019. Global tropical cyclone damages and fatalities under climate change: an updated assessment. Hurricane Risk. Springer, pp. 179-197.

10. Bandyopadhyay, S., Dasgupta, S., Khan, Z. H., \& Wheeler, D. (2018). Cyclonic Storm Landfalls in Bangladesh, West Bengal and Odisha, 1877-2016. World Bank Group.

11. Biswas, S. (2020, May 19). Amphan: Why Bay of Bengal is the world's hotbed of tropical cyclones. BBC News. https://www.bbc.com/news/world-asia-india-52718531

12. Chaturvedi, A. (2020, May 20). Cyclone Amphan: List of deadly storms in Bay of Bengal in last 30 years. Hindustan Times. https://www.hindustantimes.com/india-news/cyclone-amphan-list-of-deadly-storms-in-bay-of-bengal-in-last-30-years/storyz5FEdpXnpJOYRb6dAVxL3L.html

13. Chou, J., Dong, W., Tu, G., \& Xu, Y. (2019). Spatiotemporal distribution of landing tropical cyclones and disaster impact analysis in coastal China during 1990-2016. Physics and Chemistry of the Earth, Parts A/B/C, 102830.

14. Cortés-Ramos, J., Farfán, L. M., \& Herrera-Cervantes, H. (2020). Assessment of tropical cyclone damage on dry forests using multispectral remote sensing: The case of Baja California Sur, Mexico. Journal of Arid Environments, 178, 104171.

15. Dasgupta, S., Huq, M., Khan, Z.H., Ahmed, M.M.Z., Mukherjee, N., Khan, M.F., Pandey, K., 2011. Cyclones in a Changing Climate: The Case of Bangladesh. Department for Environment, Food and Rural Affairs, London.

16. Dieu, T.B., Tien-Chung, H., Pradhan, B., Pham, B.T., Nhu, V-H., Revhaug, I., 2016. GIS-based modeling of rainfall-induced landslides using data mining-based functional trees classifier with AdaBoost, Bagging, and MultiBoost ensemble frameworks. Environ. Earth Sci. 75, 1101.

17. Dolman, D. I., Brown, I. F., Anderson, L. O., Warner, J. F., Marchezini, V., \& Santos, G. L. P. (2018). Re-thinking socio-economic impact assessments of disasters: The 2015 flood in Rio Branco, Brazilian Amazon. International Journal of Disaster Risk Reduction, 31, 212-219. https://doi.org/10.1016/j.ijdrr.2018.04.024

18. Dube, S., Jain, I., Rao, A., Murty, T., 2009. Storm surge modelling for the bay of Bengal and Arabian Sea. Nat. Hazards 51 (1), 3-27.

19. Gao, Y.,Wang, H., Liu, G., Sun, X., Fei, X.,Wang, P., Lv, T., Xue, Z., He, Y., 2014. Risk assessment of tropical storm surges for coastal regions of China. Journal of Geophysical Research: Atmospheres 119 (9), 5364-5374.

20. GoB. (2008). Cyclone Sidr in Bangladesh- Damage, Loss and Needs Assessment for Disaster Recovery and Reconstruction. Power, February, 177.

21. Hallegatte, S. (2015). The Indirect Cost of Natural Disasters and an Economic Definition of Macroeconomic Resilience. Policy Research Working Papers, July, 1-40. https://www.gfdrr.org/sites/gfdrr.org/files/documents/Public finance and macroeconomics, Paper 3.pdf

22. Haque, A., \& Jahan, S. (2015). Impact of flood disasters in Bangladesh: A multi-sector regional analysis. International Journal of Disaster Risk Reduction, 13, 266-275. https://doi.org/10.1016/j.ijdrr.2015.07.001

23. Haraguchi, M., Cian, F., \& Lall, U. (2019). Leveraging Global and Local Data Sources for Flood Hazard Assessment and Mitigation: An Application of Machine Learning to Manila. Contributing Paper to the 2019 UN Global Assessment on Disaster Risk Reduction, 1-39.

24. Hoque, M. A. A., Pradhan, B., Ahmed, N., \& Roy, S., 2019. Tropical cyclone risk assessment using geospatial techniques for the eastern coastal region of Bangladesh. Science of The Total Environment, 692, 10-22.

25. Hoque, M.A.-A., Phinn, S., Roelfsema, C., Childs, I., 2017. Tropical cyclone disaster management using remote sensing and spatial analysis: a review. International Journal of Disaster Risk Reduction 22, 345-354

26. Hoque, M.A.-A., Phinn, S., Roelfsema, C., Childs, I., 2018. Assessing tropical cyclone risks using geospatial techniques. Appl. Geogr. 98, 22-33. 
27. Islam, M.A., Mitra, D., Dewan, A., Akhter, S.H., 2016. Coastal multi-hazard vulnerability assessment along the Ganges deltaic coast of Bangladesh-a geospatial approach. Ocean \& Coastal Management 127, 1-15.

28. Islam, T., Peterson, R., 2009. Climatology of landfalling tropical cyclones in Bangladesh 1877-2003. Nat. Hazards 48 (1), 115-135.

29. Jeyaseelan, A. T. (2003). Droughts \& floods assessment and monitoring using remote sensing and GIS. Satellite Remote Sensing and GIS Applications in Agricultural Meteorology, 291-313. http://www.wamis.org/agm/pubs/agm8/Paper-14.pdf

30. Joyce, K.E., Belliss, S.E., Samsonov, S.V.,McNeill, S.J., Glassey, P.J., 2009. A reviewof the status of satellite remote sensing and image processing techniques for mapping natural hazards and disasters. Prog. Phys. Geogr. 33 (2), 183-207.

31. Karim, M.F., Mimura, N., 2008. Impacts of climate change and sea-level rise on cyclonic storm surge floods in Bangladesh. Glob. Environ. Chang. 18 (3), 490-500.

32. Khan,M.S.A., 2008. Disaster preparedness for sustainable development in Bangladesh. Disaster PrevManag 17 (5), $662-671$.

33. Krapivin, V.F., Soldatov, V.Y., Varotsos, C.A., Cracknell, A.P., 2012. An adaptive information technology for the operative diagnostics of the tropical cyclones; solar-terrestrial coupling mechanisms. J. Atmos. Sol. Terr. Phys. 89, 83-89.

34. Kumar, A., Done, J., Dudhia, J., Niyogi, D., 2011. Simulations of Cyclone Sidr in the Bay of Bengal with a high-resolution model: sensitivity to large-scale boundary forcing. Meteorog. Atmos. Phys. 114 (3-4), 123-137.

35. Kunte, P.D., Jauhari, N., Mehrotra, U., Kotha, M., Hursthouse, A.S., Gagnon, A.S., 2014. Multi-hazards coastal vulnerability assessment of Goa, India, using geospatial techniques. Ocean \& Coastal Management 95, 264-281.

36. Mallick, B., Ahmed, B., Vogt, J., 2017. Living with the risks of cyclone disasters in the south-western coastal region of Bangladesh. Environments 4 (1), 13.

37. Mendelsohn, R., Emanuel, K., Chonabayashi, S., Bakkensen, L., 2012. The impact of climate change on global tropical cyclone damage. Nat. Clim. Chang. 2 (3), 205-209.

38. Mohammady, M., Pourghasemi, H.R., Pradhan, B., 2012. Landslide susceptibility mapping at Golestan Province, Iran: A comparison between frequency ratio, Dempster-Shafer, and weights-of-evidence models. J. Asia Earth Sci. 61 (SI), 221-236.

39. Moon, I.-J., Kim, S.-H., Chan, J.C., 2019. Climate change and tropical cyclone trend. Nature 570 (7759), E3.

40. Mori, N., Takemi, T., 2016. Impact assessment of coastal hazards due to future changes of tropical cyclones in the North Pacific Ocean. Weather and Climate Extremes 11, 53-69.

41. Murakami, H.,Wang, B., Li, T., Kitoh, A., 2013. Projected increase in tropical cyclones near Hawaii. Nat. Clim. Chang. 3 (8), 749.

42. Needham, H.F., Keim, B.D., Sathiaraj, D., 2015. A review of tropical cyclone-generated storm surges: global data sources, observations, and impacts. Rev. Geophys. 53, 545-591. https://doi.org/10.1002/2014RG000477.

43. Paul, B.K., Dutt, S., 2010. Hazard warnings and responses to evacuation orders: the case of Bangladesh's cyclone SIDR*. Geogr. Rev. 100 (3), 336-355.

44. Pinto. D.N. (2020, May 20). Sorrow of the Bay: Cyclone Hotbed Bay of Bengal Continues to Drive Storms Towards India, Bangladesh. The Weather Channel India. https://weather.com/en-IN/india/news/news/2020-05-20-cyclone-amphan-indiabangladesh-bay-of-bengal-hotbed-cyclones

45. Poompavai, V., Ramalingam, M., 2013. Geospatial analysis for coastal risk assessment to cyclones. Journal of the Indian Society of Remote Sensing 1-20.

46. Pradhan, B., Hasan, M.A., Jebur, M.N., Tehrany, M.S., 2014. Land subsidence susceptibility mapping at Kinta Valley (Malaysia) using the evidential belief function model in GIS. Nat. Hazards 73 (2), 1019-1042

47. Pradhan, B., Lee, S., 2010. Regional landslide susceptibility analysis using back-propagation neural network model at Cameron Highland, Malaysia. Landslides 7 (1), 13-30.

48. Pundir, D., Chowdhury, S. and Bhasin, S., 2020, May 21. Cyclone Amphan Highlights: Impact Worse Than Coronavirus: Mamata Banerjee on Cyclone Amphan. NDTV. https://www.ndtv.com/india-news/cyclone-amphan-live-updates-cycloneamphan-likely-to-hit-west-bengal-today-2231828

49. Quader, M.A., Khan, A.U., Kervyn, M., 2017. Assessing risks from cyclones for human livesand livelihoods in the coastal region of Bangladesh. Int. J. Environ. Res. Public Health14 (8), 831.

Loading [MathJax]/jax/output/CommonHTML/jax.js 
50. Ranson, M., Kousky, C., Ruth, M., Jantarasami, L., Crimmins, A., Tarquinio, L., 2014. Tropical and extratropical cyclone damages under climate change. Clim. Chang. 127 (2), 227-241

51. Rashid, A.K.M.M., 2013. Understanding vulnerability and risks. In: Shaw, R., Mallick, F., Islam, A. (Eds.), Disaster Risk Reduction Approaches in Bangladesh. Disaster Risk Reduction. Springer Japan, pp. 23-43.

52. Ravikiran (2020). Cyclone and its Management in India. IAS Express. https://www.iasexpress.net/cyclone-india-management/

53. Roy, K., Kumar, U., Mehedi, H., Sultana, T., \& Ershad, D. M. (2009). Initial Damage Assessment Report of Cyclone AlLA with focus on Khulna District. May, 31pp. https://doi.org/10.13140/RG.2.1.5193.3925

54. Roy, D.C., Blaschke, T., 2013. Spatial vulnerability assessment of floods in the coastal regions of Bangladesh. Geomatics, Natural Hazards and Risk 1-24 ahead-of-print.

55. Sahoo, B., Bhaskaran, P.K., 2018. Multi-hazard risk assessment of coastal vulnerability from tropical cyclones-a GIS based approach for the Odisha coast. J. Environ. Manag. 206, 1166-1178.

56. Sarwar,M.G.M., 2013. Sea-level rise along the coast of Bangladesh. In: Shaw, R.,Mallick, F., Islam, A. (Eds.), Disaster Risk Reduction Approaches in Bangladesh. Springer, Tokyo, pp. 217-231.

57. Shultz, J.M., Russell, J., Espinel, Z., 2005. Epidemiology of tropical cyclones: the dynamics of disaster, disease, and development. Epidemiol. Rev. 27 (1), 21-35.

58. Tay, C. W. J., Yun, S. H., Chin, S. T., Bhardwaj, A., Jung, J., \& Hill, E. M. (2020). Rapid flood and damage mapping using synthetic aperture radar in response to Typhoon Hagibis, Japan. Scientific Data, 7(1), 1-9. https://doi.org/10.1038/s41597020-0443-5

59. TBS Report. (2020, May 19). A brief history of the deadliest cyclones in the Bay of Bengal. The Business Standard. https://tbsnews.net/environment/brief-history-deadliest-cyclones-bay-bengal-83323

60. TET Report. (2020, May 22). Cyclone Amphan considered even more destructive than Cyclone Aila: UN. The Economic Times. https://economictimes.indiatimes.com/news/politics-and-nation/cyclone-amphan-considered-even-more-destructive-thancyclone-aila-un/articleshow/75886057.cms

61. Varotsos, C.A., Efstathiou, M.N., Cracknell, A.P., 2015. Sharp rise in hurricane and cyclone count during the last century. Theor. Appl. Climatol. 119 (3), 629-638.

62. Varotsos, C.A., Efstathiou,M.N., 2013. Is there any long-termmemory effect in the tropical cyclones? Theor. Appl. Climatol. 114 $(3-4), 643-650$.

63. Walsh, K.J., McBride, J.L., Klotzbach, P.J., Balachandran, S., Camargo, S.J., Holland, G., Knutson, T.R., Kossin, J.P., Lee, T.c., Sobel, A., 2016. Tropical cyclones and climate change. Wiley Interdiscip. Rev. Clim. Chang. 7 (1), 65-89.

64. Yin, J., Xu, S., Wang, J., Zhong, H., Hu, Y., Yin, Z., Wang, K., Zhang, X., 2010. Vulnerability assessment of combined impacts of sea level rise and coastal flooding for China's coastal region using remote sensing and GIS. Geoinformatics, 2010 18th International Conference on. IEEE, pp. 1-4.

65. Ying, M., Zhang, W., Yu, H., et al., 2014. An overview of the China meteorological administration tropical cyclone database. J. Atmos. Ocean. Technol. 3, 287-301. https://doi.org/10.1175/JTECH-D-12-00119.1.

66. Youssef, A.M., Al-Kathery, M., 2015. Landslide susceptibility mapping at Al-Hasher area, Jizan (Saudi Arabia) using GIS-based frequency ratio and index of entropy models. Geosci. J. 19 (1), 113-134.

67. Zare,M., Pourghasemi, H.R., Vafakhah, M., Pradhan, B., 2013. Landslide susceptibility mapping at Vaz Watershed (Iran) using an artificial neural network model: a comparison between multilayer perception (MLP) and radial basic function (RBF) algorithms. Arab. J. Geosci. 6 (8), 2873-2888.

68. Sud, Vedika; Rajaram, Prema (2020). "Cyclone Amphan caused an estimated \$13.2 billion in damage in India's West Bengal: government source". CNN. Retrieved 22 May 2020.

69. Aljazeera (2020). "Many killed as Cyclone Amphan tears into India, Bangladesh coasts". Retrieved 30September 2020.

70. Kossin, J. P. (2018). A global slowdown of tropical-cyclone translation speed. Nature, 558(7708), 104-107. https://doi.org/10.1038/s41586-018-0158-3

71. Hagenauer, J., \& Helbich, M. (2016). SPAWNN: A Toolkit for SPatial Analysis With Self-Organizing Neural Networks. 
72. Uddin, K., Matin, M. A., \& Meyer, F. J. (2019). Operational flood mapping using multi-temporal Sentinel-1 SAR images: A case study from Bangladesh. Remote Sensing, 11(13). https://doi.org/10.3390/rs11131581

73. World Meteorological Organization Communications and Public Affairs Office Final. (2011). Strengthening of Risk Assessment and Multi-hazard Early Warning Systems for Meteorological, Hydrological and Climate Hazards in the Caribbean. 1(1082), 186.

74. ODI. (2013). The geography of poverty, disasters and climate extremes in 2030, Research Report and Study, Overseas Development Institute, UK. 88. http://www.odi.org/sites/odi.org.uk/files/odi-assets/publications-opinion-files/8633.pdf

75. Abdullah, A. Y. M., Masrur, A., Gani Adnan, M. S., Al Baky, M. A., Hassan, Q. K., \& Dewan, A. (2019). Spatio-temporal patterns of land use/land cover change in the heterogeneous coastal region of Bangladesh between 1990 and 2017. Remote Sensing, 11(7), 1-28. https://doi.org/10.3390/rs11070790

76. Anderson, J. R., Hardy, E. E., Roach, J. T., \& Witmer, R. E. (1976). A Land Use and Land Cover Classification System for Use with Remote Sensor Data. United States Geological Survey Professional Paper, 964.

\section{Figures}

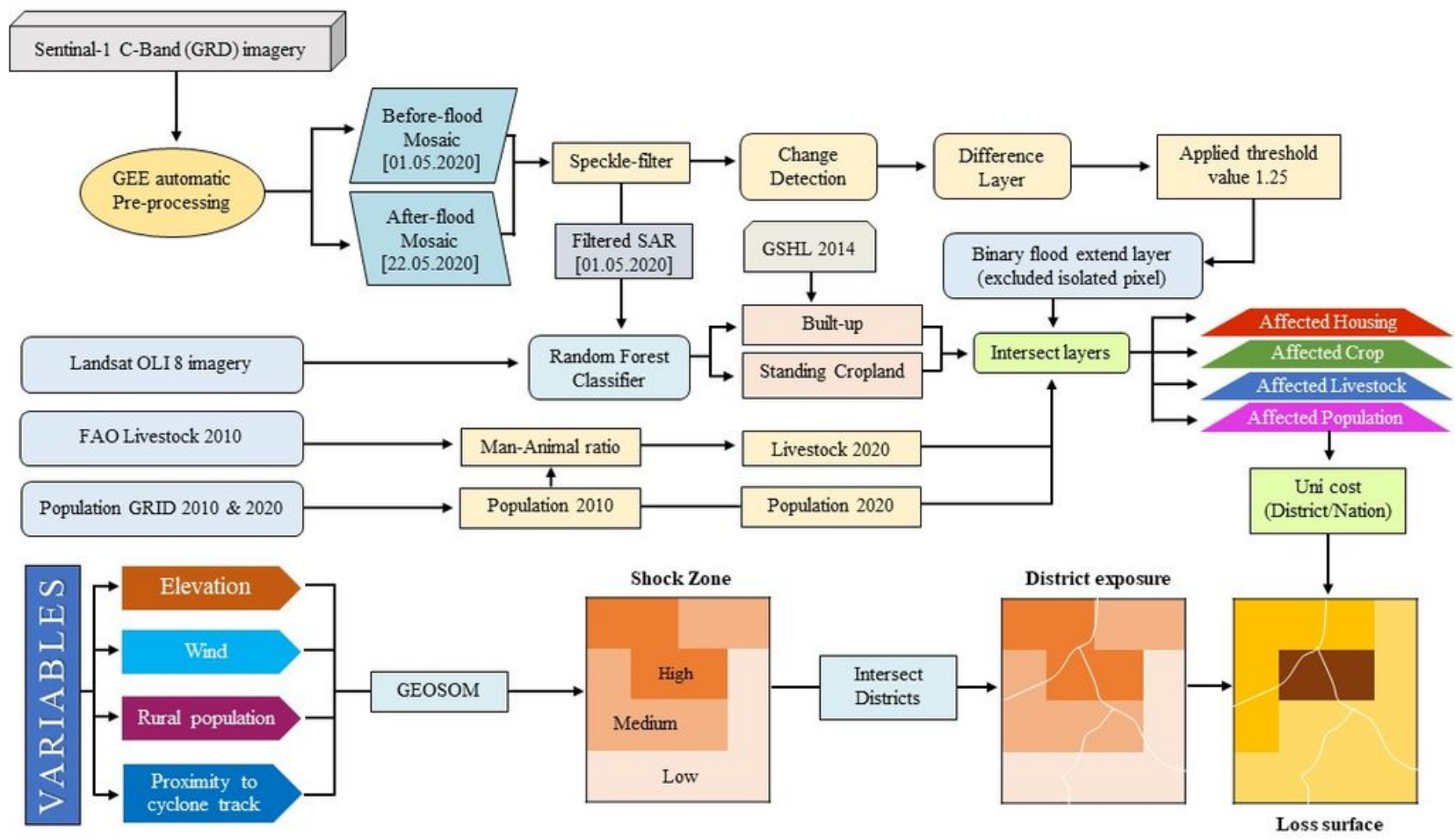

Figure 1

Workflow of the spatial damage assessment framework 

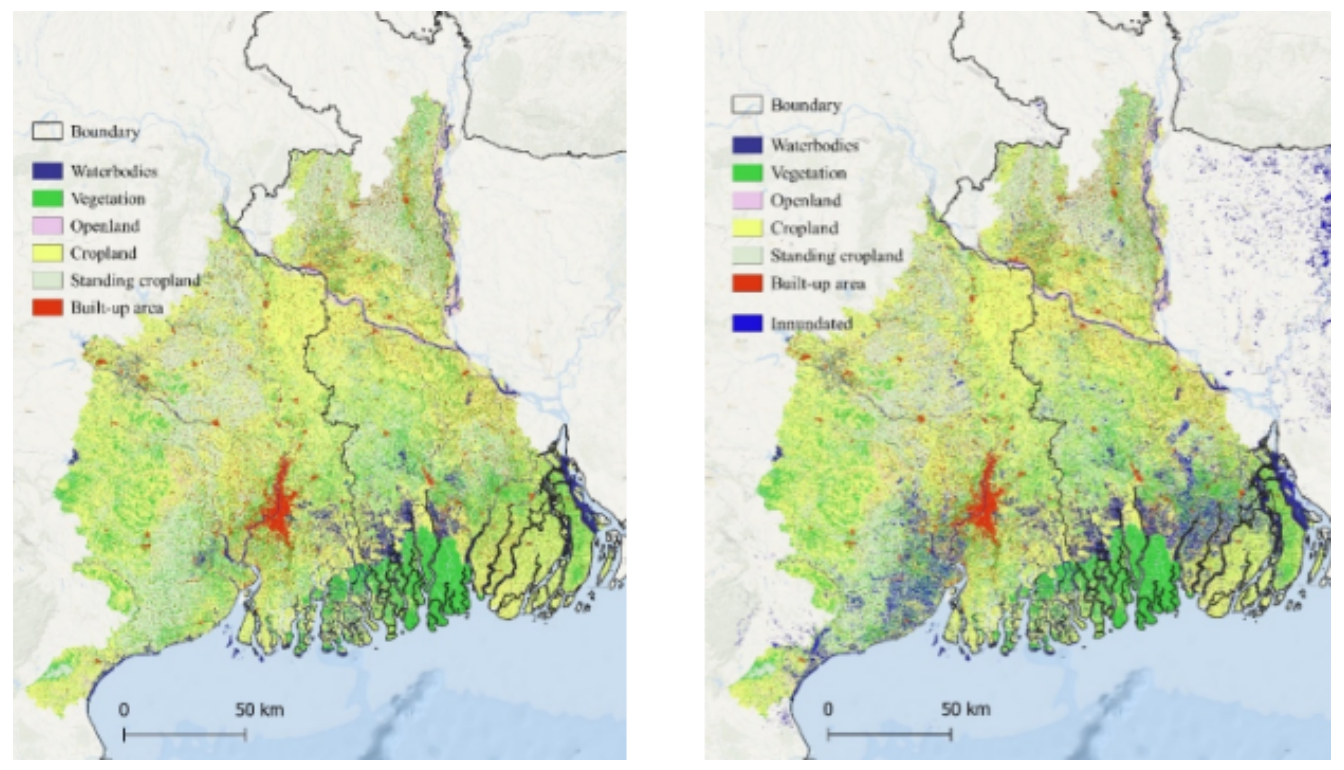

Figure 2

Land use land cover map of the study area; Left: LULC 1st May 2020; Right: LULC (1st May 2020) map and inundated area (20th May 2020)

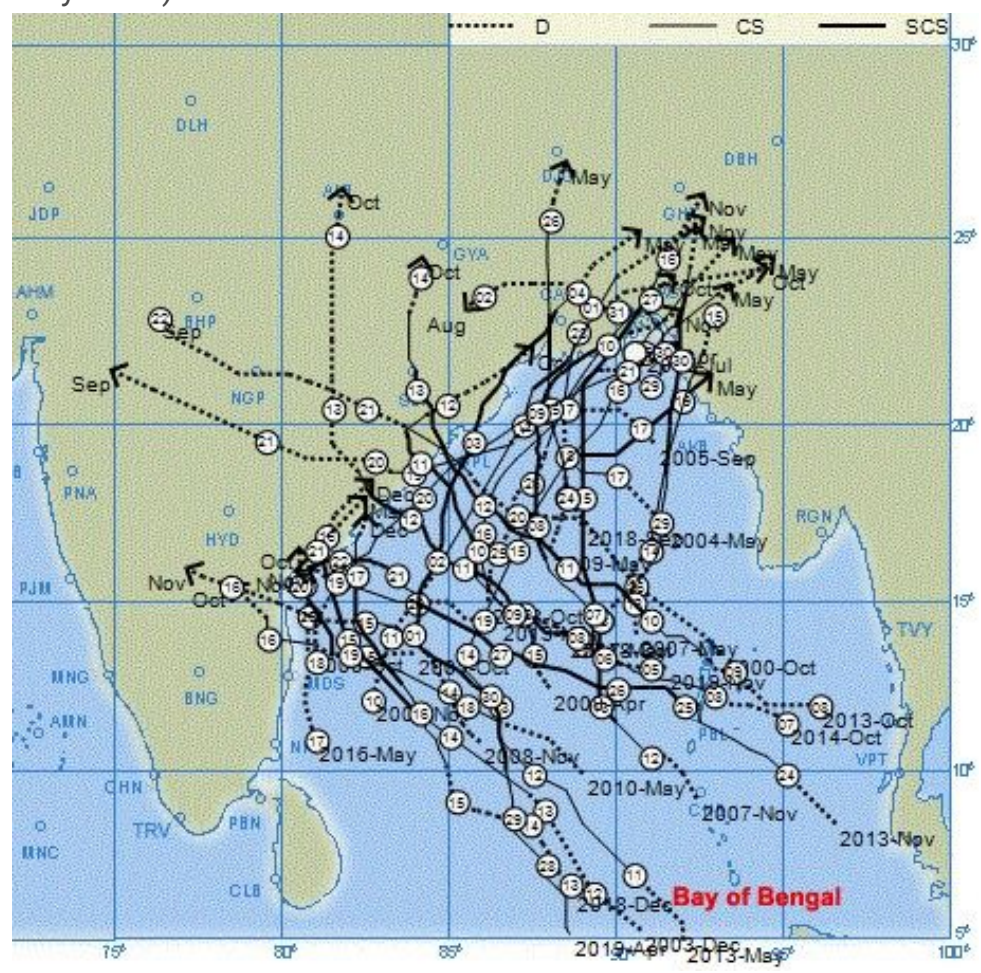

\section{Figure 3}

Tracks of cyclones and depressions for the period of 2000-2019 (Source: Cyclone e-Atlas, IMD) 


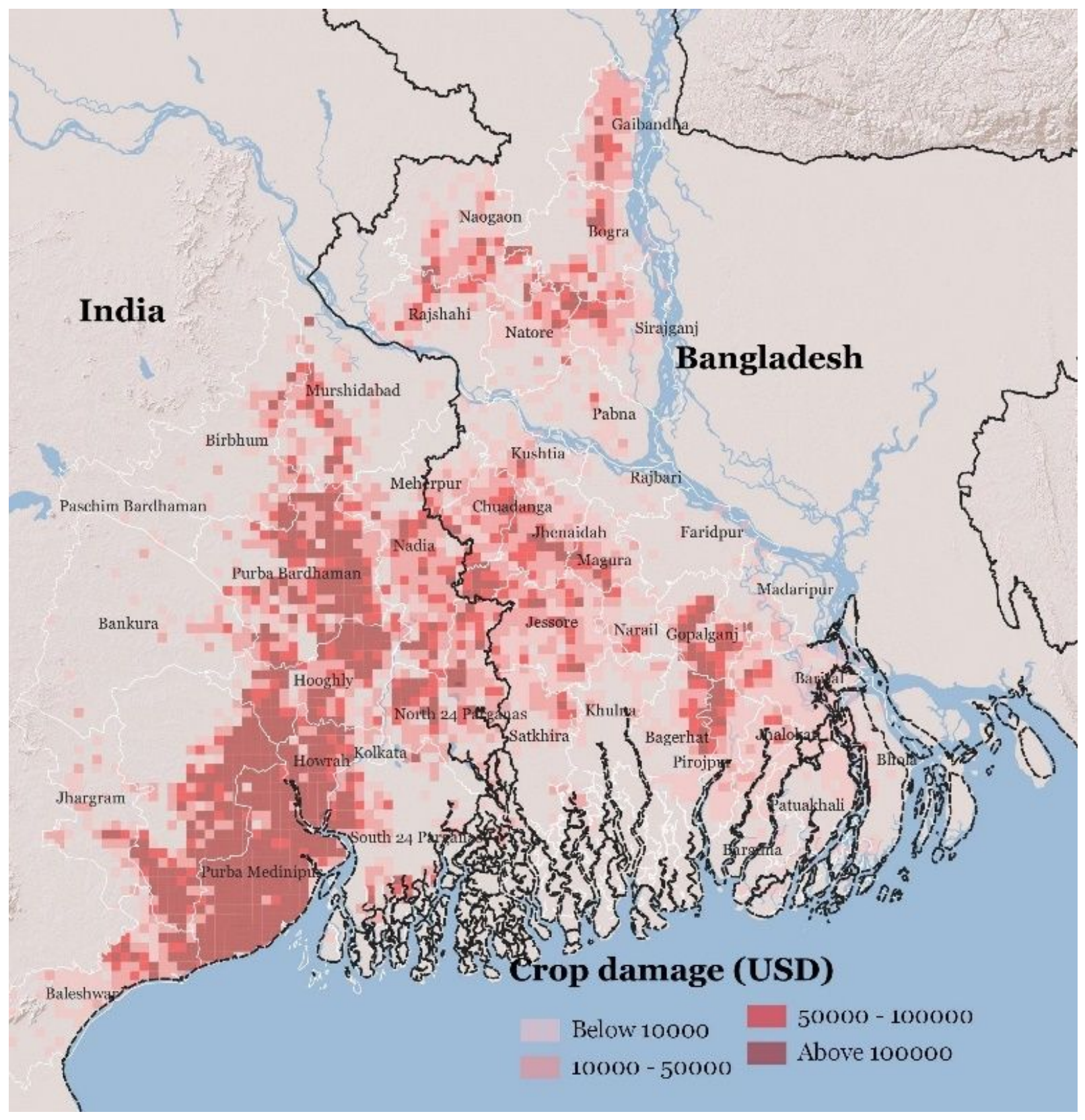

Figure 4

Estimated crop damage areas due to inundation 


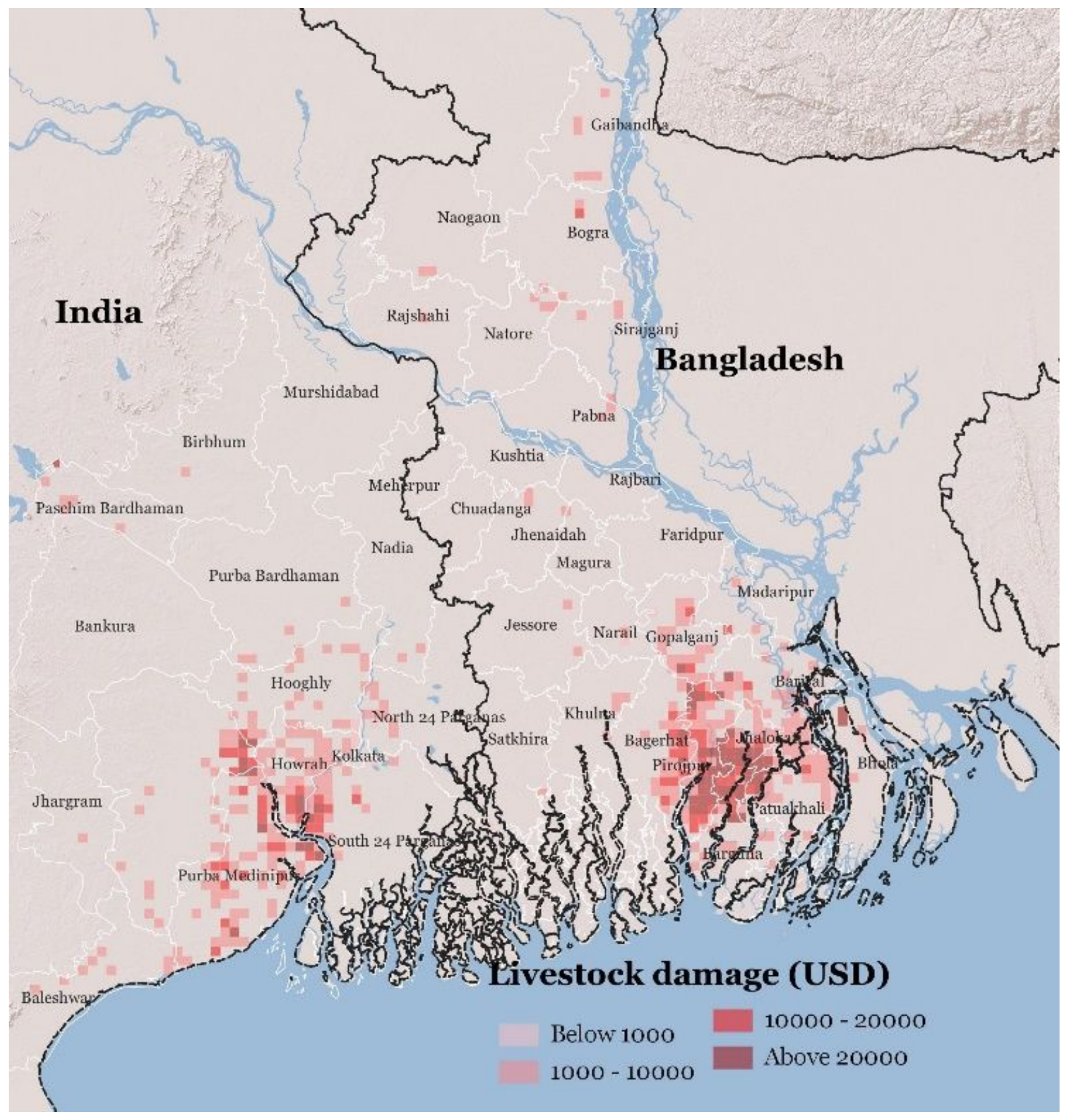

Figure 5

Estimated livestock damage area due to inundation 


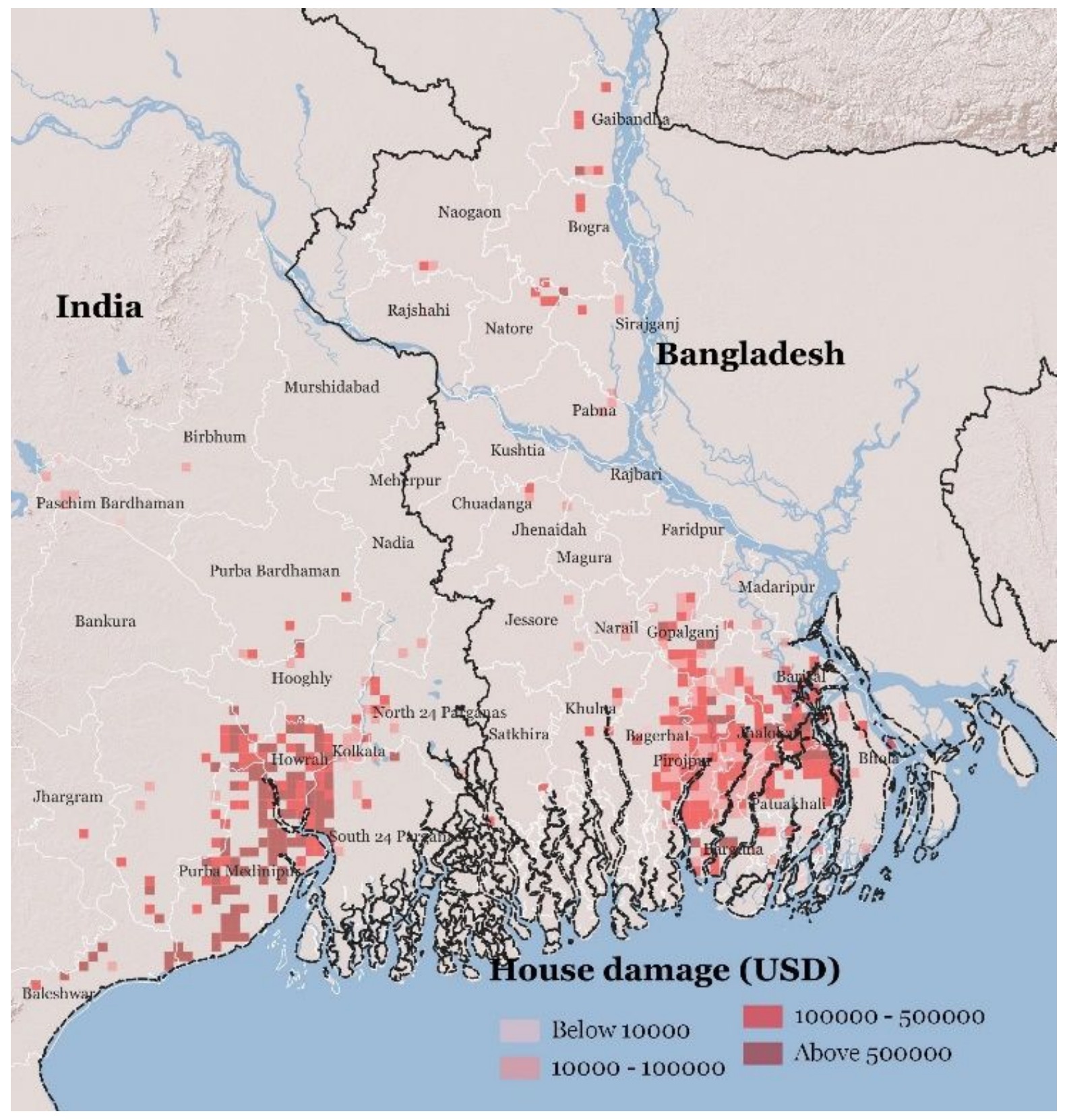

Figure 6

Estimated housing damage area due to inundation 


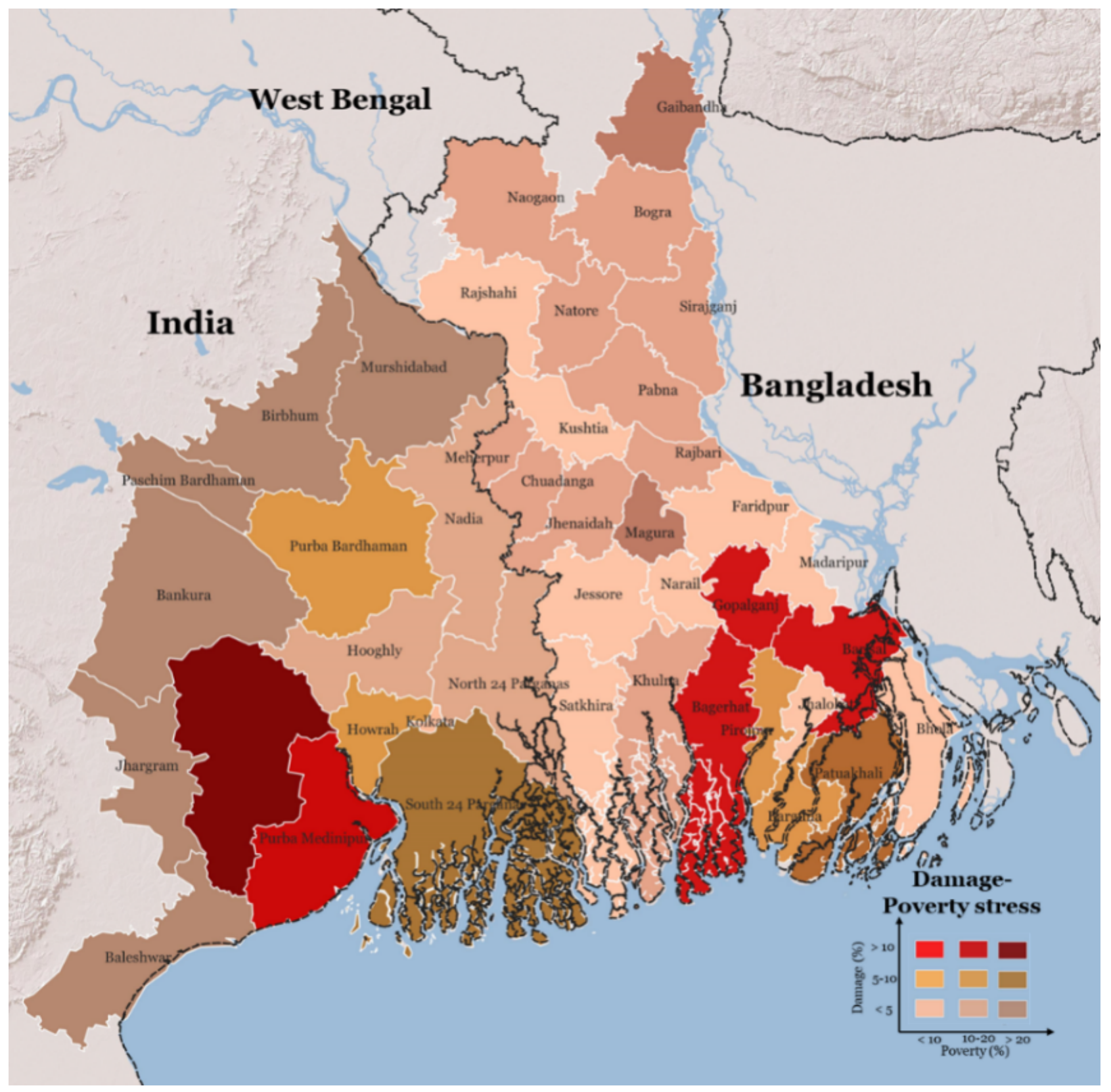

Figure 7

Association between poverty and damage intensity 


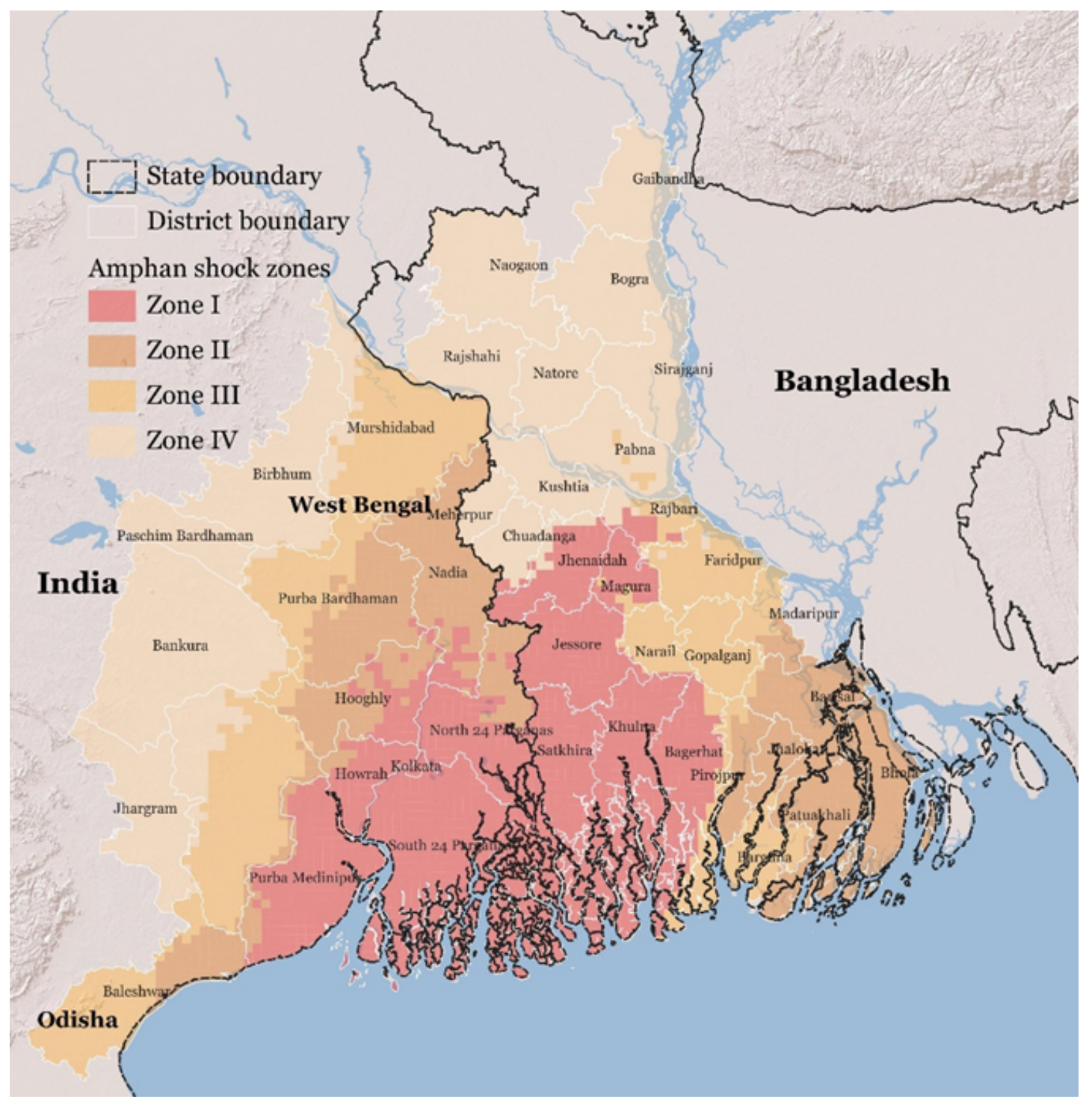

\section{Figure 8}

Estimated cyclone 'Amphan' shock zones

\section{Supplementary Files}

This is a list of supplementary files associated with this preprint. Click to download.

- Supplementaryfile.docx 